\title{
MUOKKAUSKERROKSEN ALLA OLEVIEN MAAKERROSTEN MERKITYKSESTÄ KASVINVILJELYSSÄ.
}

\author{
Martti Salonen \\ Yliopiston kasvinviljelystieteen laitos.
}

Saapunut 6. 2. 1951.

\section{Johdanto.}

On vanhastaan tunnettua, että pohjamaa, so. muokkauskerroksen alla oleva koskematon maa, on paljon huonompaa kasvualustana kuin muokkauskerros. Esim. sellaiset kohdat pellolla, joista muokkauskerros tai ns. ruokamulta on poistettu, ovat huonosti kasvavia. Toisinaan on saatu ikäviä kokemuksia, kun muokkauskerroksen paksuutta on lisätty kyntämällä pohjamaata muokkauskerroksen maan sekaan. Kuitenkin viljelyskasvien juuret yleisesti menevät pohjamaahan, jopa huomattavan syvällekin (15). Olisi mielenkiintoista ja useassa suhteessa myös hyödyllistä tietää, mikä merkitys pohjamaahan menevillä juurilla on kasvien kasvussa.

Ei ole läheskään selvää, mistä kaikista tekijöistä pohjamaan huonous kasvualustana johtuu. Fysikaalisista tekijöistä voisi päätellä, että ainakin kosteutta pohjamaassa voi olla paremmin kuin pintakerroksessa. Ilmavuus- 1. happisuhteet taas ovat varsinkin tiiveissä maalajeissa sitä huonommat mitä syvemmästä kerroksesta on kysymys, mutta sellainen ilmiö kuin maan halkeilu voi esim. savimaassa paljon vaikuttaa syvempien kerrosten ilmavuussuhteisiin. Pohjamaalla ei ole ns. mururakennetta, vaan se on liettyneessä tilassa. Kasvien juuret eivät yleensä voi tunkeutua aivan tiiviiseen maahan, vaan ne- esiintyvät enemmän tai vähemmän irrallisina halkeamissa ja rei'issä. On ilmeistä, etteivät juuret sellaisissa olosuhteissa voi toimia täysin tehokkaasti. Myös kemiallisilla suhteilla voi päätellä olevan paljon merkitystä. Esim. typpeä ei humusköyhässä pohjamaassa voi olla sanottavasti. Myös helposti liukenevan fosforin määrät näyttävät pohjamaassa yleensä olevan pienemmät kuin muokkauskerroksessa. Kalia sensijaan voi pohjamaassa esiintyä runsaastikin (8). Eräissä tapauksissa voi myös kalkkia olla vähän ja happamuus suuri, mutta sellaisissa tapauksissa myös juurten tunkeutuminen pohjamaahan 
on hyvin vähäistä (15). Biologisesti vaikuttavat humuksen vähyys ja pieneliötoiminnan huonot mahdollisuudet. Pohjamaassa ei voi tapahtua niitä mikrobiologisia ilmiöitä, joilla on suuri vaikutus muokkauskerroksen hedelmällisyyteen.

Pohjamaalla voidaan ajatella eräissä tapauksissa olevan jopa ratkaiseva vaikutus kasvien menestymiseen. Pitkän poutakauden aikana voi muokkauskerros kuivua läpeensä, ja silloin kasvit joutuvat kokonaan syvemmältä saatavan veden ja ravinteiden varaan. Voidaan päätellä, että vettä yleensä aina on saatavissa pohjamaasta, mutta epäilyksiä siinäkin suhteessa herättää juurien heikko yhteys maa-ainekseen, joka ilmenee useissa tapauksissa (15, s. 80). Jo pelkän veden saantikin on erittäin hyvä, sillä kasvit voivat sen varassa ainakin pysyä hengissä, mutta jotta myös jatkuva kasvu olisi mahdollinen, pitää olla myös edes vähän kasvinravintoaineitakin saatavissa.

\section{Aikaisempia tutkimuksia.}

Yleensä on saatu sellainen käsitys, että kasvit ottavat vettä ja ravinteita koko siltä alalta, missä juuria esiintyy (13, s. 145), siis useissa tapauksissa hyvinkin syvältä. Tästä on olemassa suoranaisia tutkimustuloksiakin. CHRIst ja WEAver (4) sijoittivat kasvinravintoaineita eri syvyyksiin ja selvittivat eri tapauksissa käytetyt määrät, jolloin he tulivat sellaiseen tulokseen, että kasvit kykenevät ottamaan typpeä ja fosforia hyvinkin syvästä. Hunter ja Kelley (6) ovat vastaavanlaisissa tutkimuksissa käyttäneet hyvin pitkälle kehitettyä tekniikkaa. He voivat osoittaa, että kasvi ottaa esim. fosforia $120 \mathrm{~cm}$ syvyydestä. LADEFOGED (10) on suorittanut luonnollisissa olosuhteissa tutkimuksia koivun juurten toiminnasta eri maakerroksissa. Hän otti juurinestettä erilaisissa syvyyksissä toimivista juuriston osista (toimintasyvyys todettiin juurinesteen keräämisen jälkeen). Hän totesi, että kosteana aikana koivu otti typpeä, kalia ja kalkkia enemmän pintaosista kuin syvemmältä, mutta kuivana aikana suhteet olivat tasaisemmat. Fosforin otto oli kaikissa olosuhteissa huomattavan tasaista eri syvyyksistä. Vastaavanlaiset tutkimukset eivät valitettavasti ole mahdollisia pienikokoisilla, ruohomaisilla kasveilla.

Kasvit siis kykenevät ottamaan vettä ja ravinteita suurestakin syvyydestä, jos niitä vain on olemassa käyttökelpoisessa muodossa. Alway, McDole ja Rost (1) tulivat sellaiseen tulokseen, että ravinteiden, ei vain typen, vaan myös fosforin ja kalinkin, puute on hyvin vaikuttava tekijä pohjamaan huonoudessa. MillaR (12) totesi, että astiakokeissa pohjamaa antoi kauralla typpilannoituksesta huolimatta vain $\mathrm{n}$. puolet siitä sadosta, mitä vastaava muokkauskerroksen maa antoi. Apila sensijaan kasvoi eräissä tapauksissa pohjamaassa jopa paremmin kuin vastaavassa muokkauskerroksen maassa, jos se oli ympätty. Tämä viittaisi siihen, että typen puute vaikuttaa eniten kasvien huonoon kasvuun pohjamaassa. van der MERve (11) taas tuli sellaiseen tulokseen, että fosforin puute on pohjamaan huonouteen eniten vaikuttava tekijä. SHANTz (16) totesi, että humidisessa savimaan pohjamaassa on vesi niin lujasti sidottuna, että kasvit eivät voi sitä ottaa. Sama seikka tulee vielä vakuuttavampana näkyviin KARRAKerin ja BORTNERin 
tutkimuksessa, josta ilmenee, että tällaisesta maasta kasvit eivät ole voineet ottaa vettä $60 \mathrm{~cm}$ syvempää.

Eräät tutkijat, kuten esim. Ferrant ja Sprague (5), Bushnell (3) sekä WoOdRUFF ja Smith (17) ovat pellolla kokeilleet erilaisten pohjamaan käsittelyjen, kuten möyhennyksen, kalkituksen ja erilaisen lannoituksen vaikutusta juurien kehittymiseen ja satotuloksiin. Varsinkin möyhennys ja kalkitus yhdessä sekä fosforin lisääminen paransivat juurien tunkeutumista pohjamaahan, mutta maanpäällinen sato ei aina parantunut.

Mainituissa tutkimuksissa on pohjamaa joutunut tavallisuudesta poikkeavaan olotilaan. Näin on asianlaita varsinkin silloin, kun tutkimus tehdään astiakokeena, jolloin maa pakosta on nimenomaan fysikaalisesti toisenlaista kuin ollessaan koskemattomana muokkauskerroksen alla. Tavallisen viljelyksen kannalta olisi kuitenkin tarpeellisinta tietää, mikä arvo pohjamaalla on kasveille juuri sellaisena kuin se on normaalisessa peltomaassa. Tämän seikan tutkimiseksi suunnittelin erikoisen koemenettelyn, jonka mukaan tavallisessa peltomaassa voidaan kasvattaa kasveja siten, että muokkauskerros ei pääse vaikuttamaan, vaan kasvit joutuvat kasvamaan pelkästään pohjamaasta saatavien aineiden turvin.

\section{Koemenettely.}

Menettelytavassa, jota sovelsin, tapahtuu muokkauskerroksen pois sulkeminen kasveilta siten, että ne saavat kasvaa puhtaalla kvartsihiekalla täytetyssä lasiputkessa, joka ulottuu muokkauskerroksen läpi. Vasta sen alla on juurilla tilaisuus levittäytyä maahan. Useiden kasvien itämisjuuret (primääriset juuret) voivat pelkästään siemenen vararavinnon turvin kasvaa riittävän pitkiksi. Juurten kasvu suuntautuu aina alaspäin, joten kerran muokkauskerroksen alle johdetut juuret eivät enää käänny ylöspäin (kuva 1). Alustavien havaintojen mukaan ainakin kaura ja herne voivat kasvaa tällaisissa ahtaissa putkissa. Mainittakoon, että Pohjakallio (14) on muita tarkoituksia varten käyttänyt vastaavantapaista järjestelyä, jossa siinäkin kasvien juuret alkuun saivat kasvaa hiekkakerroksen läpi ja vasta sen alla pääsivät ravinteita sisältävään maahan.

Muokkauskerroksen paksuus on meillä $20 \mathrm{~cm}$ tai vähemmän. Jotta siis koko muokkauskerros voitaisiin ottaa pois kasveilta, tar-

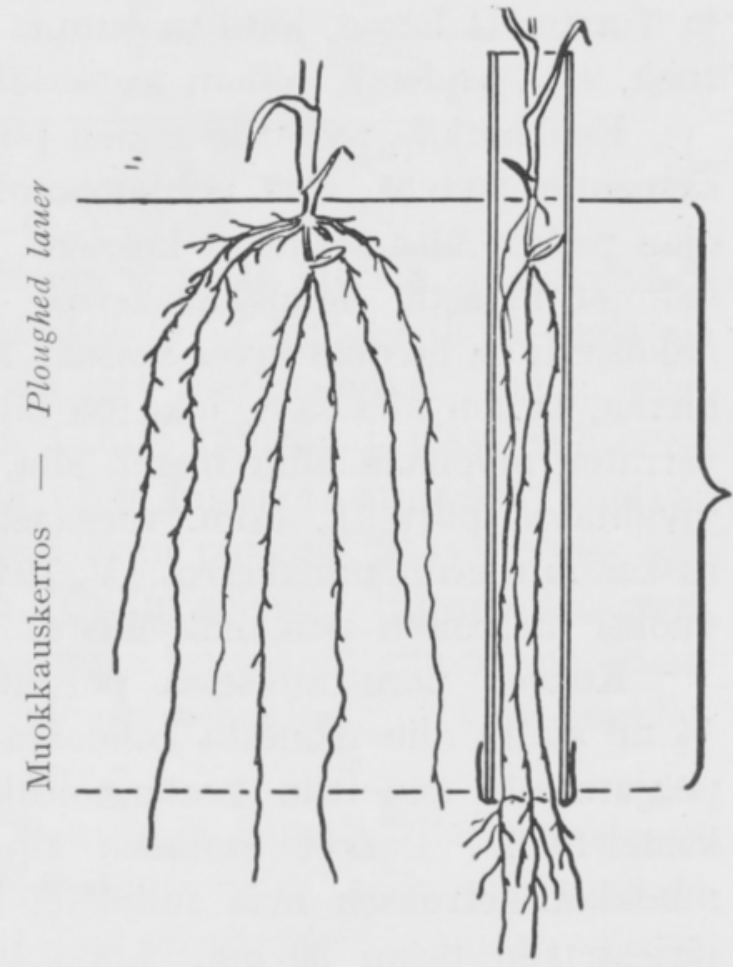

Kuva 1. Kaavakuva juurien sijoittumisesta tavalliseen tapaan kasvavalla ja lasiputkessa kasvavalla kasvilla.

Fig. 1. Scheme of the position of plant roots for the roots of control plant and plant growing in glass tube. 
vitaan vähintään $20 \mathrm{~cm}$ pituiset putket. Lyhemmillä putkilla voidaan ottaa osa muokkauskerroksesta. On vielä tarpeen, että putki ulottuu jonkinverran muokkauskerroksen pinnan yläpuolelle, jottei esim. sade pääse roiskuttamaan maata putkeen.

Kokeissa käytetyt putket olivat tavallista suoraa lasiputkea, läpim. 19-23 mm, joka katkaistiin halutun mittaisiksi pätkiksi, ja päät pyöristettiin kuumentamalla. Jotta hiekka olisi saatu pysymään putkessa, varustettiin alapää harvalla pellavakankaalla, joka kiinnitettiin putken ympäri käärityllä eristysnauhalla. Lopuksi kangas kastettiin kuumaan parafiiniin, jottei se aivan pian lahoaisi maassa.

Putkien täytteenä käytettiin hienoa, valkeaa kvartsihiekkaa, joka oli pesty ensin laimealla suolahapolla ja sitten runsaalla vedellä ja lopuksi kuivattu ja hehkutettu. Hiekka pantiin putkiin sopivan tuoreeksi kostutettuna ja siihen kylvettiin vuorokauden ajan vedessä liotetut siemenet. Putkia pidettiin alkuun 5 vrk. laboratoriossa, jotta itäminen ja oraiden alkukehitys voisi tapahtua mahdollisimman suotuisasti ennen sijoittamista lopulliseen kasvupaikkaan koekentällä.

\section{Esikokeet v. 1949.}

Koemenettelyn käyttökelpoisuutta tutkittiin esikokeen luontoisissa pikku kokeissa Viikissä ns. koekenttäalueella 1949. Koekasveina oli Kultasade II kaura ja Torstai II herne, joita molempia kasvatettiin sekä yksinään, puhtaana kasvustona, että yhdessä, jolloin kumpaakin kasvilajia oli samassa putkessa.

Koekentällä todettiin ennen putkien sijoitusta ja vapaasti kasvavien kasvien siementen kylvöä, että pohjamaa oli koskematon, sillä esim. ent. avo-ojan tai salaojan paikka olisi sotkenut kokeen. Vasta kokeen loputtua tehtiin tarkemmat havainnot maasta. Muokkauskerros oli näissä kokeissa hietamultaa, jossa todennäköisesti on hieman savea seassa. Muokkauskerroksen alla oli $10 \mathrm{~cm}$ paksu kerros hietaa, ja sen alla savi, joka on lähinnä hietasavea. Kun maa on alavaa, on se verraten myöhään ollut meren alla, ja sen vuoksi savessa on hieman urpasaveen vivahtavia piirteitä, esim. runsaasti esiintyvien halkeamien pinnoissa on selvä ruskea rautasakkaumakerros. V. 1949 käytetty koemaa oli siis tuon hietakerroksen vuoksi melkoisen poikkeuksellista.

Kokeen perustamisessa poistettiin ensin muokkauskerroksen maa tarkoin $1 / 2 \mathrm{~m}^{2}$ alalta niin monesta kohdasta kuin kokeeseen tuli koejäseniä. Paljastetulle pohjamaalle annettiin koelannoitukset, joiden imeytymistä maahan edistettiin kastelemalla. Putket oraineen sijoitettiin sitten valmistetulle pohjamaalle ja muokkauskerroksen maa sullottiin huolellisesti takaisin, jolloin sen paksuudeksi järjestettiin tasan $20 \mathrm{~cm}$. Lopuksi kylvettiin siemenet vapaasti kasvavia koekasveja varten.

Koekasvien kasvu oli jokseenkin säännöllinen, lukuunottamatta sitä, että muutamissa putkissa kasveja kuoli. Koekasvien korjuu tehtiin hieman ennen täyttä tuleentumista, mutta saatu siemen oli kuitenkin jo itävää. Sadon korjuu tehtiin yksin kappalein, ja samalla suoritettiin havainnot juurten esiintymisestä eri 
maakerroksissa. Todettiin että vapaasti kasvavien kasvien juuristot täyttivät tasaisena verkostona koko muokkauskerroksen, mutta pohjamaahan meni vain muutamia harvoja juuria. Ilmeisesti hietakerros heti muokkauskerroksen alla oli esteenä juurien tunkeutumiselle. Koko muokkauskerroksen läpi johtavissa putkissa kasvaneissa kaurayksilöissä olivat sekundääriset juuret hyvin heikosti kehittyneitä. Niiden ei missään tapauksessa todettu menevän pohjamaahan asti. Sensijaan primääriset itämisjuuret kyllä tulivat putkista ulos ja tunkeutuivat pohjamaahan n. $10 \mathrm{~cm}$ syvälle.

Maanpäällinen sato kuivattiin huonekuivaksi, minkä jälkeen kaikki koekasvit punnittiin yksitellen, jolloin otettiin ensin kokonaispaino, sitten poimittiin jyvät, joiden lukumäärä laskettiin ja paino punnittiin. Kaikki punnitukset tehtiin cg tarkkuudella. Satotuloksista esitettäköön vain toisessa esikokeessa kauralla saadut kokonaispainot, taulukko 1.

Taulukko 1. Esikokeessa 1949 saadut kokonaissadot kasviyksilöä kohti kauralla, cg.

Table 1. Total yields per plant in centigrammes in the preliminary experiment with oats in 1949.

\begin{tabular}{lcc} 
Koelannoitus & Vapaasti kasvaneet kasvit & $20 \mathrm{~cm}$ putkissa kasvaneet kasvit \\
Fertilization treatment & Control plants & Test plants grown in $20 \mathrm{~cm}$. tubes \\
O & $293 \pm 35$ & $24 \pm 9$ \\
N & $312 \pm 19$ & $55 \pm 15$ \\
NP & $368 \pm 30$ & $53 \pm 12$ \\
NK & $283 \pm 18$ & $28 \pm 7$ \\
NPK & $278 \pm 27$ & $62 \pm 12$ \\
\hline keskim. - aver. & $307 \pm 12$ & $44 \pm 6$
\end{tabular}

Keskiarvojen keskivirheet ovat suuret johtuen suurista eroista eri kasviyksilöiden välillä ja koekasvien vähäisistä lukumääristä $(6-7 \mathrm{kpl})$. Niinpä eroja eri lannoitusten välillä ei saada tilastomatemaattisesti merkitseviksi, mutta erot vapaasti kasvaneiden ja putkissa kasvaneiden välillä täyttävät tässä suhteessa suuretkin vaatimukset (2, s. 43-47). Mikäli saatujen lukujen perusteella voidaan päätellä koelannoitusten vaikutusta, näyttää se olevan putkissa kasvaneisiin kasveihin tehokkaampi kuin vapaasti kasvaneisiin. Onkin selvää, että annettu pieni koelannoitus ei voi vaikuttaa sanottavia maassa, joka on saanut runsaanpuoleisen peruslannoituksen. Typen vaikutus näyttäisi olevan tehokkaampi kuin muiden ravinteiden.

Esikokeiden mukaan voidaan siis ainakin kauraa ja hernettä kasvattaa koemenettelyn mukaan. Näyttää ilmeiselle, että kasvit voivat saada pohjamaasta ainakin pieniä määriä kehitykselleen välttämättömiä aineita, joskin niiden vähyyden vuoksi kasvu jää pieneksi. Sekundääristen juurien pois jäämisen ei tarvitse olla varsin suuri häiriö, sillä on osoitettu, että primääriset itämisjuuret ovat täysarvoisia juuria, jotka säilyvät toimintakykyisinä yksivuotisen kasvin koko elinajan (9). Koekasveissa muodostuu siemensatoakin, ja siemenet kehittyvät suunnilleen normaalisen kokoisiksi, mutta lukumäärä jää vähäiseksi. Kaura näytti sopivan tällaiseen kokeeseen paremmin kuin herne. 


\section{Koe kesällä 1950.}

Kokeen perustaminen ja hoito. Koekenttä sijoitettiin nytkin Viikkiin lohkolle L5a, jossa maa on lähinnä hietasavea myös muokkauskerroksessa eikä siinä esiinny sellaista häiritsevää hietakerrosta kuin edellisen vuoden koekentällä. Sadon korjuun jälkeen otetuista maanäytteistä tehtiin Maatalouskoelaitoksen Maatutkimusosastossa ns. viljavuustutkimukseen kuuluvat määritykset, joissa saatiin seuraavat tulokset:

\begin{tabular}{|c|c|c|}
\hline & $\begin{array}{c}\text { muokkaus- } \\
\text { kerros }\end{array}$ & $\begin{array}{l}\text { pohjamaa } \\
25-35 \mathrm{~cm}\end{array}$ \\
\hline H-luku & 5.9 & 5.8 \\
\hline aihtuva kalkki, $\mathrm{CaCO}_{3} \mathrm{tn} / \mathrm{ha} \ldots$. & 13.4 & 10.5 \\
\hline lposti liukeneva fosforihappo, $\mathrm{P}_{2} \mathrm{O}_{5} \mathrm{~kg} / \mathrm{ha} \ldots \ldots$ & 270 & 60 \\
\hline lposti liukeneva kali, $\mathrm{K}_{2} \mathrm{O} \mathrm{kg} / \mathrm{ha} \ldots \ldots \ldots \ldots \ldots$ & 2100 & 1350 \\
\hline
\end{tabular}

Happamuudessa sekä kalkki- ja kalipitoisuudessa ei ole suurta eroa eri maakerrosten välillä, mutta helposti liukenevaa fosforihappoa on pohjamaassa vain neljäs osa siitä mitä muokkauskerroksessa. Maa oli edellisenä syksynä kynnetty nurmesta. Koeruutujen valmistuksessa maa hienonnettiin perusteellisesti ja esiintyvät nurmiturpeet poistettiin. Samalla todettiin, että pohjamaa oli koskematon. Koekentän valmistus ja kylvö tehtiin 15. 5. Siinä meneteltiin samalla tavalla kuin edellisen vuoden esikokeissakin. Muokkauskerroksen maa poistettiin tarkoin $71 \times 71 \mathrm{~cm}=0.5 \mathrm{~m}^{2}$ alalta, koelannoitteet levitettiin tasoitetulle pohjamaalle, ja niiden imeytymistä maahan edistettiin kastelemalla. Käytetyt koelannoitteet olivat:

N 10 g kalkkisalpietaria $\quad 1 / 2 \mathrm{~m}^{2}$ kohti
P 10 " superfosfaattia
K $10 " 40 \%$ kalisuolaa

Määrät vastaavat $200 \mathrm{~kg} / \mathrm{ha}$. Käytetyt lannoiteyhdistelmät nähdään taulukosta 2. Koekasvina oli vain Kultasade II kaura. Putkiin oli siemen kylvetty 5 päivää aikaisemmin, joten niissä oli orastuminen jo alussa. Käytettyjen $25 \mathrm{~cm}$ putkien sijoituksessa meneteltiin siten, että putket pystytettiin pohjamaahan painettuihin $0.5 \mathrm{~cm}$ syviin reikiin, joten juurilla ei voisi olla mitään mahdollisuutta päästä kosketuksiin muokkauskerroksen maan kanssa. Muutamiin lannoitusruutuihin tuli myös $10 \mathrm{~cm}$ pituisia putkia, joiden avulla kasveilta voitiin ottaa 6 $\mathrm{cm}$ muokkauskerroksen pinnasta. Putket sijoitettiin kunkin koeruudun toiseen puoliskoon, ja muokkauskerroksen maa sullottiin huolellisesti paikollleen, jolloin sen syvyydeksi järjestettiin tasan $20 \mathrm{~cm}$. Tämän jälkeen kylvettiin siemenet vapaasti kasvavia koekasveja varten. Koeruutujen väleihin ja ympärille kylvettiin lopuksi pari riviä kauraa suojakaistaksi. Tuholaisten varalta maa pölytettiin heti runsaasti Agrocidella. 
Putkiin kylvettyjen siementen lukumäärät olivat kussakin koejäsenessä $35-40 \mathrm{kpl} 25 \mathrm{~cm}$ putkissa ja $25-28 \mathrm{kpl} 10 \mathrm{~cm}$ putkissa. Putkiin kylvetyistä kasveista kuoli kuitenkin huomattava osa pian sen jälkeen kun putket sijoitettiin ulos, mihin mahdollisesti eniten vaikutti pitkään jatkuneet koleat säät. Henkiin jääneiden kasvien lukumäärät eri koejäsenissä nähdään taulukosta 2. Tuholaisten torjumiseksi uusittiin Agrocide pölytys vielä kaksi kertaa, mutta siitä huolimatta esiintyi hieman kahukärpäsen aiheuttamaa tuhoa vapaasti kasvaneissa yksilöissä. Heinäkuun puolivälissä ilmestyi koekasveihin runsaasti tummia kirvoja, mutta ne onnistuttiin täysin hävittämään ruiskuttamalla E 605 liuoksella ennenkuin ehtivät tehdä tuntuvampaa haittaa. Kesän kuivuus ei näyttänyt pahemmin häiritsevän koekasveja. Kasvun aikana pantiin merkille, että $10 \mathrm{~cm}$ putkissa kasvavat kasvit olivat jopa kookkaampia kuin vapaasti kasvavat. $25 \mathrm{~cm}$ putkissa kasvavat koekasvit kehittyivät jokseenkin normaalisesti, mutta jäivät hyvin paljon pienemmiksi kuin muut.

Sadon korjun tapahtui 21. 8., jolloin kaura ei ollut vielä täysin tuleentunut. Kukin yksilö katkaistiin maanpinnalta kaikkine versoineen, numeroitiin ja pantiin kuivumaan ilmavaan laboratoriohuoneeseen.

Juuristohavainnot tehtiin heti maanpäällisen sadon korjuun jälkeen. Muokkauskerroksen maa oli tällöin melko kuivaa ja hyvin mureaa, johtuen ilmeisesti keväällä tapahtuneesta perusteellisesta muokkauksesta. Pohjamaa oli hyvin kovaa ja halkeillutta. Vapaasti kasvavien kasvien juuret muodostivat tasaisen tiheän verkoston koko muokkauskerrokseen lukuunottamatta aivan ylintä osaa. Pohjamaahan tunkeutui vain aivan harvoja juuria etupäässä halkeamia myöten. Suurin todettu syvyys oli $45 \mathrm{~cm} .10 \mathrm{~cm}$ putkissa kasvaneiden yksilöiden juuristot olivat hyvin samantapaiset kuin vapaasti kasvaneiden kasvien. Läpi koko muokkauskerroksen ulottuneissa $25 \mathrm{~cm}$ putkissa kasvaneissa yksilöissä todettiin edellisen vuoden esikokeista poiketen hyvin kehittyneitä sekundäärisiäkin juuria, joita oli $3-5$ $\mathrm{kpl}$, ja ne menivät pohjamaahan ruuduilla, joilla oli käytetty typpilannoitusta, mutta ei muissa. Mistä tämä erilaisuus sekundääristen juurien esiintymisessä näinä kahtena koevuotena johtuu, jäi ratkaisematta, mutta 1950 kokeissa oli typpilannoituksen vaikutus siihen aivan selvä. Näiden $25 \mathrm{~cm}$ putkissa kasvaneiden kasvien juuret menivät pohjamaahan yleisesti $10-15 \mathrm{~cm}$ syvyyteen.

Maanpäällisen sadon punnitukset tehtiin, kun koekasvit olivat kuivuneet laboratoriossa kaksi viikkoa ja olivat täysin huonekuivia. Punnituksessa meneteltiin samalla tavalla kuin edellisenä vuonnakin. Kukin yksilö punnittiin ensin kokonaisuudessaan, sen jälkeen poimittiin jyvät, joiden lukumäärä laskettiin ja paino punnittiin. Kaikki punnitukset tehtiin apteekkivaa'alla cg tarkkuudella. Tiedot satotuloksista nähdään taulukossa 2, jossa on esitetty myös keskiarvojen keskivirheet sekä eri eroille lasketut t-arvot kokonaispainojen mukaan (2, s. 43-47). Kun $10 \mathrm{~cm}$ putkia on ollut vain muutamissa koelannoituksissa, on vapaasti kasvaneista ja $25 \mathrm{~cm}$ putkissa kasvaneista saaduista tuloksista pantu esille myös keskiarvot niistä koejäsenistä, jotka ovat olleet edustettuina $10 \mathrm{~cm}$ putkissa. 


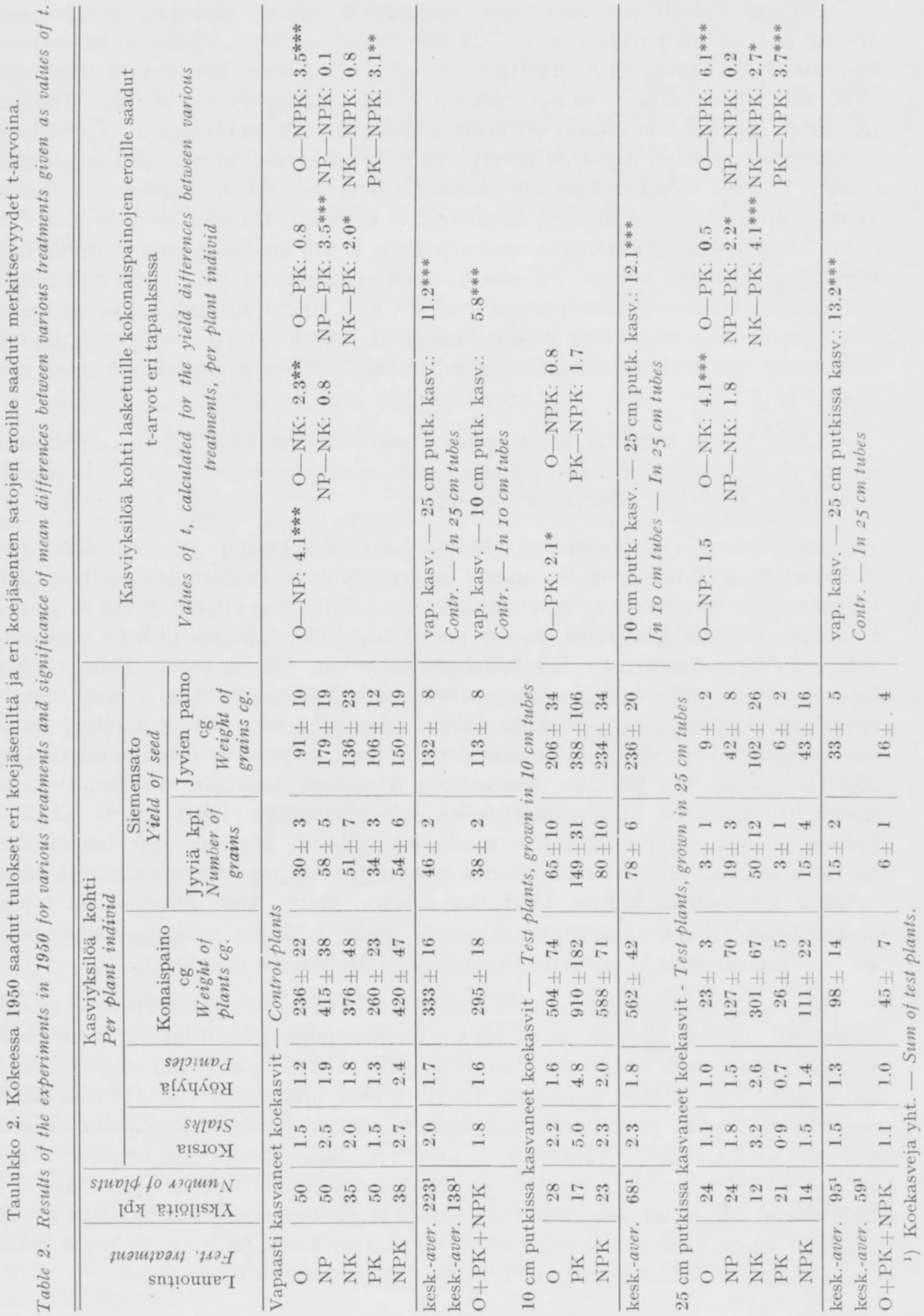




\section{Tulosten tarkastelua.}

Keskiarvojen keskivirheet ovat näissäkin koetuloksissa kauttaaltaan suuret johtuen kasviyksilöiden koon luontaisesta suuresta vaihtelusta. Putkissa kasvaneiden kasvien kohdalla nämä vaihtelut ovat suuremmat kuin vapaasti kasvaneiden kasvien kohdalla. Tämä tietysti huonontaa statistisesti merkitsevien erojen muodostumista eri koejäsenten välillä, mutta kuitenkin niitäkin saadaan, jos erot ovat suuret.

Ensiksikin pistää silmään, että $10 \mathrm{~cm}$ putkissa kasvaneet kasvit ovat kookkaampia kuin vapaasti kasvaneet, ja erotus on statistisestikin merkitsevä. Voidaan päätellä, että kuivan kasvukauden vuoksi 6 ylimmällä cm:llä maan pinnassa ei ole ollut kasveille merkitystä. Mahdollisesti on ollut eduksikin, etteivät kasvit ole muodostaneet juuria, joilla ei myöhemmin kuitenkaan ole ollut toimintamahdollisuuksia. Putkissa kasvaneet kasvit säästyivät kokonaan kahukärpäseltä, joka ahdisteli vapaasti kasvavia yksilöitä.

Ero toisaalta vapaasti ja $10 \mathrm{~cm}$ putkissa kasvaneiden ja toisaalta $25 \mathrm{~cm}$ putkissa kasvaneiden yksilöiden koossa on suuri ja statistisesti hyvin merkitsevä, mutta ei kuitenkaan niin suuri kuin esikokeissa edellisenä vuonna. Siihen ovat mahdollisesti vaikuttaneet näiden koevuosien erilaiset kosteussuhteet. Tässä yhteydessä mielenkiintoisimmasta kohdasta, eri kasvinravintoaineiden vaikutuksesta $25 \mathrm{~cm}$ putkissa kasvaneisiin kasveihin, saadaan statistisesti merkitseviä tietoja typen vaikutuksesta. Jos tarkastellaan saatuja t-arvoja, voidaan panna merkille, että sekä vapaasti kasvaneissa että $25 \mathrm{~cm}$ putkissa kasvaneissa koejäsenissä t-arvo muodostuu säännöllisesti merkitseväksi, kun vertaillaan typpilannoitusta saaneita ja ilman sitä olleita koejäseniä. Vain yhdessä tapauksessa näistä t-arvo ei ole merkitsevä (25 cm putket, vertailu $\mathrm{O}-\mathrm{NP})$, mutta siihen vaikuttaa pääasiassa koejäsenessä NP esiintyvä suuri keskiarvon keskivirhe. Siitä, että typen vaikutus on kaikkialla huomattava ja statistisesti merkitsevä, voidaan päätellä, että typen niukkuudella on suurin osuus siinä, että pohjamaa on huonoa kasvualustana. Fosforia ja kalia näyttää koemaan pohjamaassa olevan siksi paljon, että niiden pieni lisääminen ei aiheuta selvää ja varmaa sadon lisääntymistä. Tutkimuksen ulkopuolelle jäävät fysikaaliset tekijät, jotka kaikkialla ovat samat ja sellaiset, kuin ne yleensä ovat normaalisessa peltomaassa. Ne ovat tällaisessa tiiviissä savimaan pohjamaassa tietenkin hyvin epäsuotuisat, ja niillä voi olla paljonkin merkitystä.

\section{Päätelmät.}

Saatujen koetulosten mukaan muokkauskerroksen alla olevalla pohjamaalla on siinä tilassa kuin se esiintyy tavallisessa peltomaassa merkitystä kasvien kasvussa, koska kasvit voivat pelkästään sen varassa kasvaa ja kehittyä normaalisti, joskin jäävät kooltaan pieniksi. Fosforia ja kalia näyttivät kasvit saavan kokeessa olleesta maasta kohtalaisesti, mutta typen puute oli erittäin selvä. 


\section{KIRJALLISUUTTA}

(1) Alway F. J., McDole, G. R. and Rost, C. O. 1917. The loess soils of the Nebraska portion of the transition region: VI. The relative mrawness" of the subsoils. Soil Sci. 3, s. 9-35.

(2) Bonnier, G. och Tedin, O. 1940. Biologisk variationsanalys. Stockholm.

(3) Bushnell, J. 1941. Exploratory tests of subsoil treatments inducing deeper rooting of potatoes on Wooster silt loam. J. Amer. Soc. Agron. 33, s. 823-828.

(4) Christ, J. W., and Weaver, J. E. 1924. Absorption of nutrients from subsoil in relation to crop yields. Plant Phys. 77, s. 121-148.

(5) Ferrant, N. A. (Jr.), and Sprague, H. B. 1940. Effect of treating different horizons of Sassafras loam on root development of red clover. Soil Sci, 50, s. 141-161.

(6) Hunter, A. S., and Kelley, O. J. 1946. A new technique for studying the absorption of moisture and nutrients from soil by plant roots. Soil Sci. 62 , s. $441-450$.

(7) Karraker, P. E., and Bortner, C. E. 1939. Availability of soil moisture, particularly as affected by depht, in the soil of the Kentucky Exp. St. farm at Lexington. J. Amer. Soc. Agron. 31 , s. $653-660$.

(8) Keränen, T. 1946. Turvemaiden savetuksen kalilannoitusvaikutuksesta. Maatalous 39, s. $109-111$.

(9) Krassowsky, I. 1926. Physiological activity of the seminal and nodal roots of crop plants. Soil Sci. 21 , s. $307-325$.

(10) Ladefoged, K. 1948. Analysis of the root sap of the birch. Plant and Soil 1, 127-134.

(11) van der Merve, C. R. 1926. A contribution to the study of the infertility of the subsoil. J. Agr. Sci. 16 , s. $507-521$.

(12) Millar, C. E. 1925. The feeding pover of plants in different soil horizons. J. Amer. Soc. Agron. $17,150-156$.

(13) Miller, E. C. 1938. Plant physiology. New York.

(14) Pohjakallio, O. 1944. Untersuchungen über die Resistenz von Hafer gegen die Trockenperiode. Maat. Aikak. 16, s. 162-178.

(15) Salonen, M. 1949. Tutkimuksia viljelyskasvien juurten sijainnista Suomen maalajeissa. Acta Agr. Fenn. 70, 1.

(16) Shantz, H. L. 1925. Soil moisture in relation to the growth of crop plants. J. Amer. Soc. Agron. 17. s. $705-711$.

(17) Woodruff, C. M., and Smith, D. D. 1947. Subsoil shattering and subsoil liming for crop production on claypan soils. Soil Sci. Soc. Amer., Proc. 1946, Vol. 11, s. 539-542.

S U M M A R Y.

ON THE SIGNIFICANCE OF SUBSOIL TO CROP PLANTS.

By

Martti Salonen

Institute of Crop Husbandry, University of Helsinki.

The root systems of all crop plants are partly situated in subsoil, but under the conditions prevailing in Finland, the bulk of roots are in the ploughed layer. Is it then possible for plants to take water and nutrients from the subsoil? Investigations have been conducted in order to find out the significance of subsoil as the environment of roots, but experiments have been carried out either 
as pot tests, or in subsoil after removing the surface soil above it. It is evident that if the subsoil is no longer in its natural condition underneath the ploughed layer, considerable changes occur in it, at least in its physical properties. It would, however, be most interesting to find out what is the significance of the subsoil as such, in its natural condition, to plants.

In order to illustrate this problem, a test method was developed, according to which it is possible to grow plants (oats) in ordinary undisturbed soil by means of subsoil only. Seeds were sown in glass tubes and the plants grew through these without having any contact with the ploughed layer (Fig. 1). The tubes were filled with quarts sand, free of all nutrients. Roots could not spread in the soil until after penetrating through the tube. It was observed that they did not begin to grow upwards after penetrating into the soil. Control plants were grown in usual manner beside the test plants.

Yields per plant obtained from plants grown in this manner are given in centigrammes in Table 2. It is seen that it is possible for plants to grow by means of subsoil only. Individual plants of oats developed normally, they even yielded some grain, but remained very small in size. Thus subsoil can supply plants with all necessary nutrients, though their amounts are very small.

Great natural variation of individual plants resulted in high standart errors for various treatments, but mean differences between various treatments were also so great as to make the differences statistically significant. A survey of the values of $t$ in Table 2 shows that mean differences were significant between plants receiving nitrogen and those grown without nitrogen. From this it is possible to draw the conclusion that nitrogen is the nutrient the subsoil most of all lacks. 